\title{
A NEW AND EXTRAORDINARY CYRTOCHILUM (ORCHIDACEAE: ONCIDIINAE) FROM COLOMBIA
}

\author{
Giovanny Giraldo ${ }^{1} \&$ Stig Dalström ${ }^{2,3}$ \\ ${ }^{1}$ Department of Botany, University of Wisconsin-Madison, 430 Lincoln Drive, \\ Madison WI 53706-1381, U.S.A. \\ 22304 Ringling Boulevard, unit 119, Sarasota FL 34237, U.S.A. \\ Lankester Botanical Garden, University of Costa Rica, Cartago, Costa Rica \\ and National Biodiversity Centre, Serbithang, Bhutan \\ ${ }^{3}$ Corresponding author: stigdalstrom@juno.com
}

\begin{abstract}
Aвstract. A new species of Cyrtochilum from Antioquia, Colombia, is described and illustrated, and compared with the similar Ecuadorian C. cryptocopis and C. trifurcatum, but differs in having a different ventral structure and much narrower wings of the column, and also by the much broader frontlobe of the lip.
\end{abstract}

Key words: Cyrtochilum, Colombia, Oncidiinae, new species, taxonomy

Despite two centuries of intense hunting for orchids in the Colombian wilderness, as well as extensive deforestation and urbanization, new and extraordinary species are found rather frequently. New and attractive species of Phragmipedium Rolfe have recently been described, and large numbers of showy pleurothallids in genera such as Dracula Luer, and Masdevallia Ruiz \& Pav., as well as a plethora of other types of orchids never seem to stop appearing in the botanical literature. This paper describes a new Cyrtochilum Kunth, from the western cordillera where it was initially discovered by one of the authors (GG) as his attention was caught by the dancing brown and yellow flowers on the long pendant inflorescence while walking through the national preserve.

Cyrtochilum betancurii G.Giraldo \& Dalström $s p$. nov.

TYPE: Colombia, Antioquia, Mun. Urrao. Parque Nacional Natural las Orquídeas, in cloud forest at 1600-1800 m elevation. February 2, 2011. J. Betancur 14882 (holotype, COL). Fig. 1-3.

Diagnosis: Cyrtochilum betancurii is most similar to the Ecuadorian C. cryptocopis (Rchb.f.) Kraenzl. (Fig. 4), and C. trifurcatum (Lindl.) Kraenzl. (Fig. 5), but has a different ventral structure and much narrower wings of the column, and also by the much broader frontlobe of the lip.
Epiphytic herb. Pseudobulbs distant on a creeping, bracteate rhizome, oblong ovoid and slightly compressed, $c a .4 .3 \times 2.1 \mathrm{~cm}$, unifoliate or bifoliate, surrounded basally by four to six distichous foliaceous sheaths. Leaves subpetiolate, conduplicate, obovate, acute, to $c a .40 .0-50.0 \times 5.0-6.0 \mathrm{~cm}$. Inflorescence axillary from the uppermost sheath, erect then wiry, straight to loosely flexuous to $c a .2 .80 \mathrm{~m}$ long panicle, with a basal longer branch, and then several widely spaced, short, few-flowered side-branches, carrying in total 16 to 18 flowers (although larger specimens with more flowers are likely to exist). Floral bracts appressed, scale like, ca. $1.0 \times 0.6-0.7 \mathrm{~cm}$. Pedicel with ovary ca. $4.5 \mathrm{~cm}$ long. Flowers stellate and showy; dorsal sepal dark brown with yellow border, basally auriculate, spathulate, broadly cordate, distinctly undulate, obtuse to acute and slightly oblique, $3.6 \times$ $2.4 \mathrm{~cm}$; lateral sepals dark brown, basally auriculate and connate for $6.0-8.0 \mathrm{~mm}$, then spreading, elongate and narrowly spathulate, then cordate, slightly undulate, obtuse to rounded and slightly oblique, $c a$. $7.4 \times 2.3 \mathrm{~cm}$; petals dark brown with a yellow border, broadly linear and shortly spathulate, then truncate to cordate, distinctly undulate, obtuse to acute and slightly oblique, $c a .2 .5 \times 1.8 \mathrm{~cm}$; lip dark brown with yellow border and callus, rigidly attached to the base of the column through a narrow and terete claw, then truncate, distinctly pandurate with spreading, slightly oblique, broadly auriculate, slightly serrate lateral 

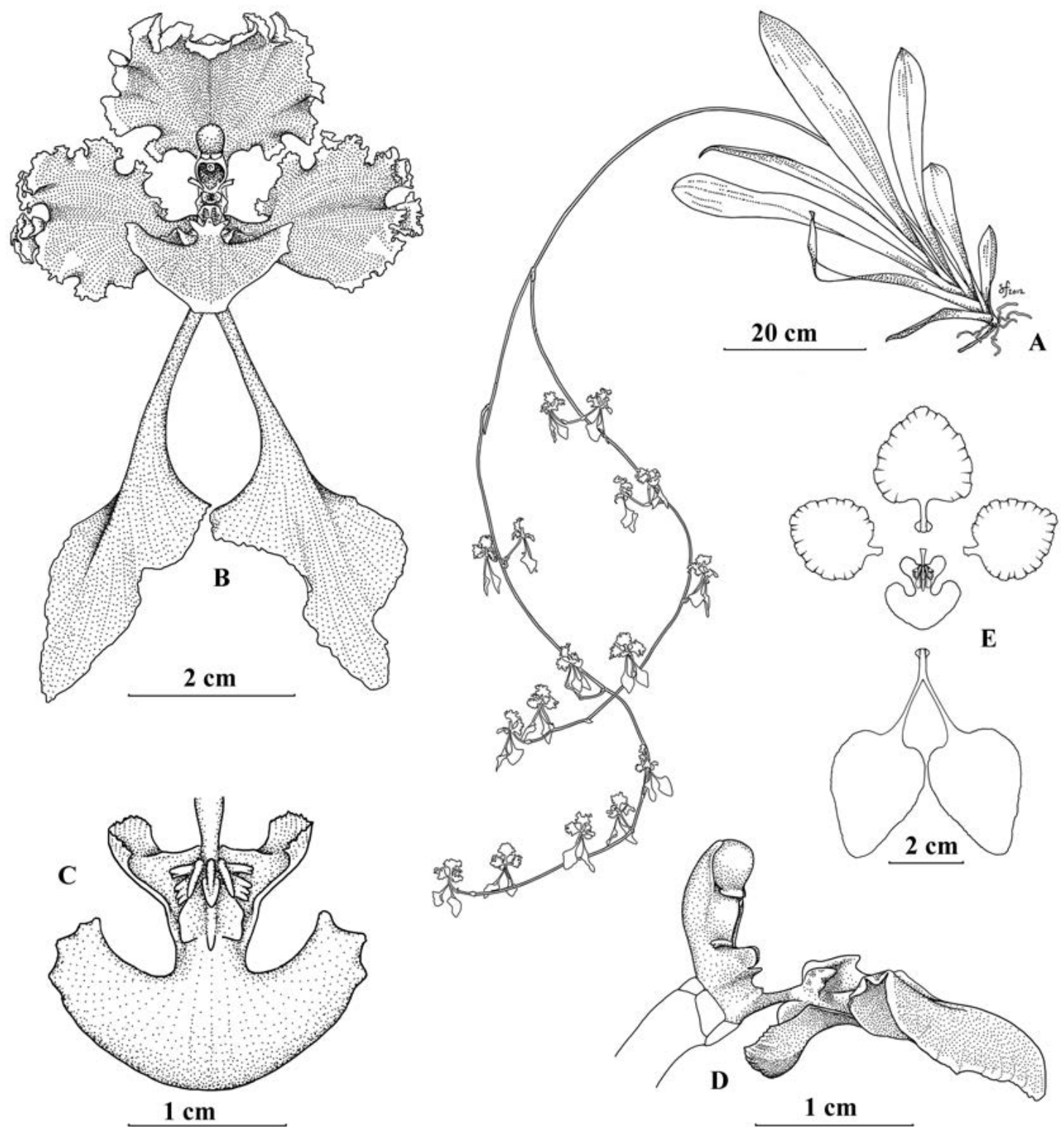

Figure 1. Cyrtochilum betancurii. A. Plant habit. B. Flower, front view. C. Lip, ventral view. D. Column and lip, lateral view. E. Flower dissected. Drawn from holotype by Sarah Friedrich.

lobes, and a ca. $4 \mathrm{~mm}$ broad isthmus below the widely spreading and broadly dolabriform, obtuse to acute, emarginate, revolute frontlobe, $1.8 \times 1.8 \mathrm{~cm}$; callus complex and fleshy, emerging near the base of the lateral lobes and extending for $c a .5 \mathrm{~mm}$, consisting of an erect, table-like, tricarinate structure with several lateral, spreading denticles, with additional series of spreading tubercles or denticles on each side, and an apical, central, longitudinal and triangular keel, with spreading, dorsally flattened, fleshy, lateral keels; column purplish brown, stout, erect in a ca. $90^{\circ}$ angle from the base of the lip then slightly curved towards the lip near the apex, with a complex, protruding, terete, trilobate concavity on the ventral side below the stigma, and with a pair of clavate to obliquely and narrowly deltoid, or bilobed, spreading blackish purple 

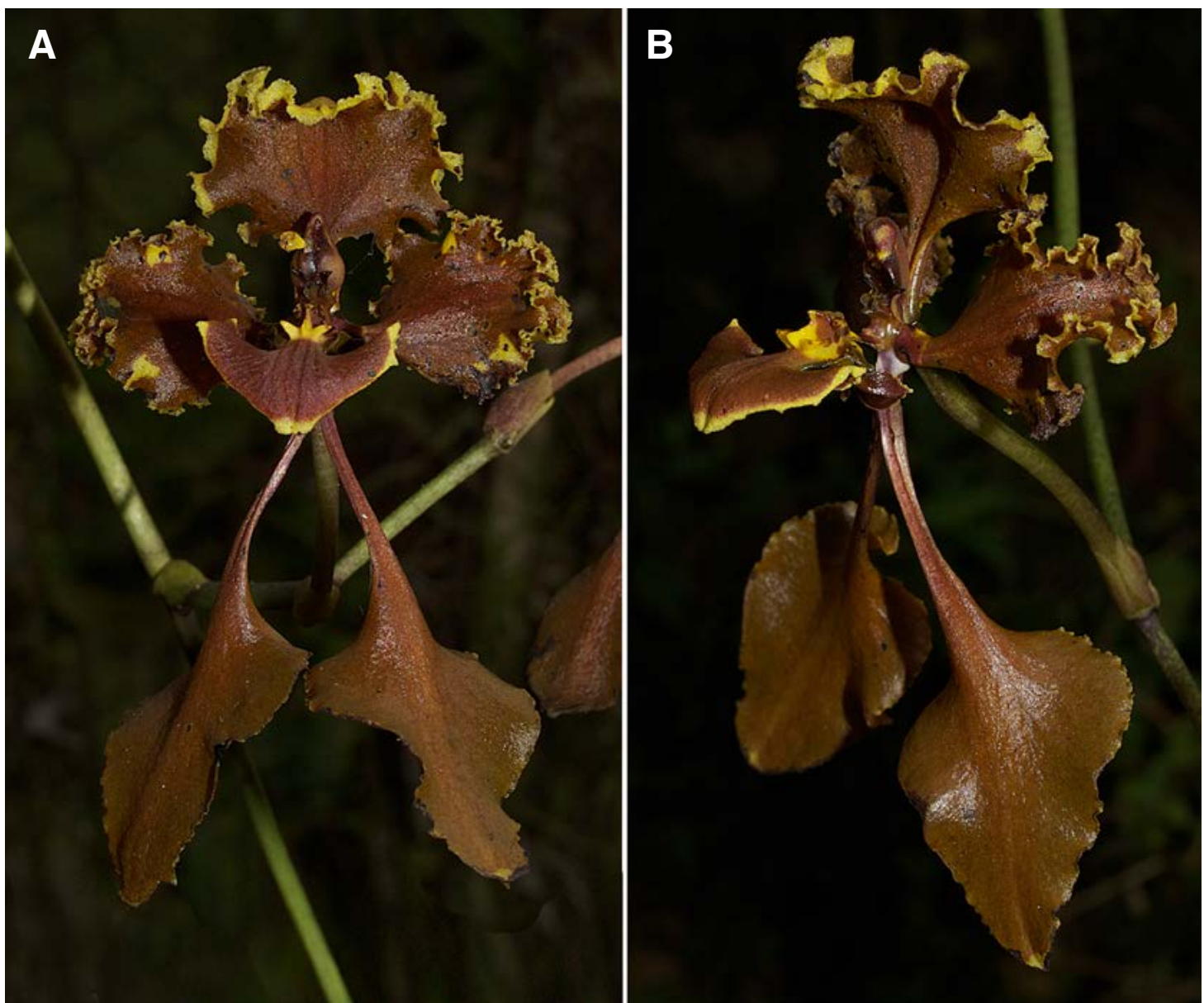

FIGURE 2. Cyrtochilum betancurii, flower in frontal (A) and lateral (B) views. Photo by G. Giraldo.

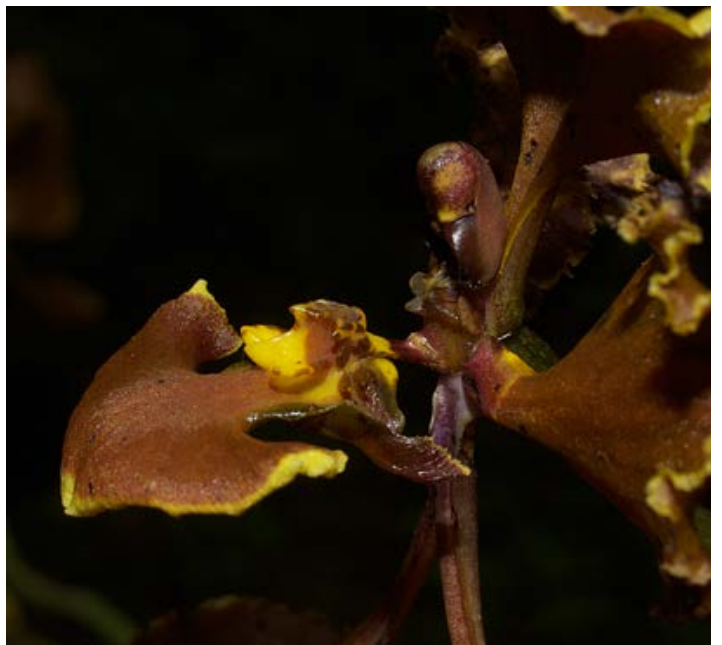

FIGURE 3. Cyrtochilum betancurii, detail of the column and lip, lateral view. Photo by G. Giraldo. wings on each side below the stigma; anthercap yellow and purplish, campanulate; pollinarium not seen.

Distribution: Colombia, Antioquia, Mun. Urrao. Parque Nacional Natural las Orquídeas on the western cordillera.

Eponymy: Named in honor of Julio Betancur, leader of the expedition to Parque Nacional Las Orquideas, and a renowned Colombian botanist with great experience and passion for tropical plants that has positively influenced a new generation of Colombian botanists.

Cyrtochilum betancurii is only known from the type collection in the cloud forests of the western cordillera in Colombia. Because of its restricted location the authors recommend its protection until 

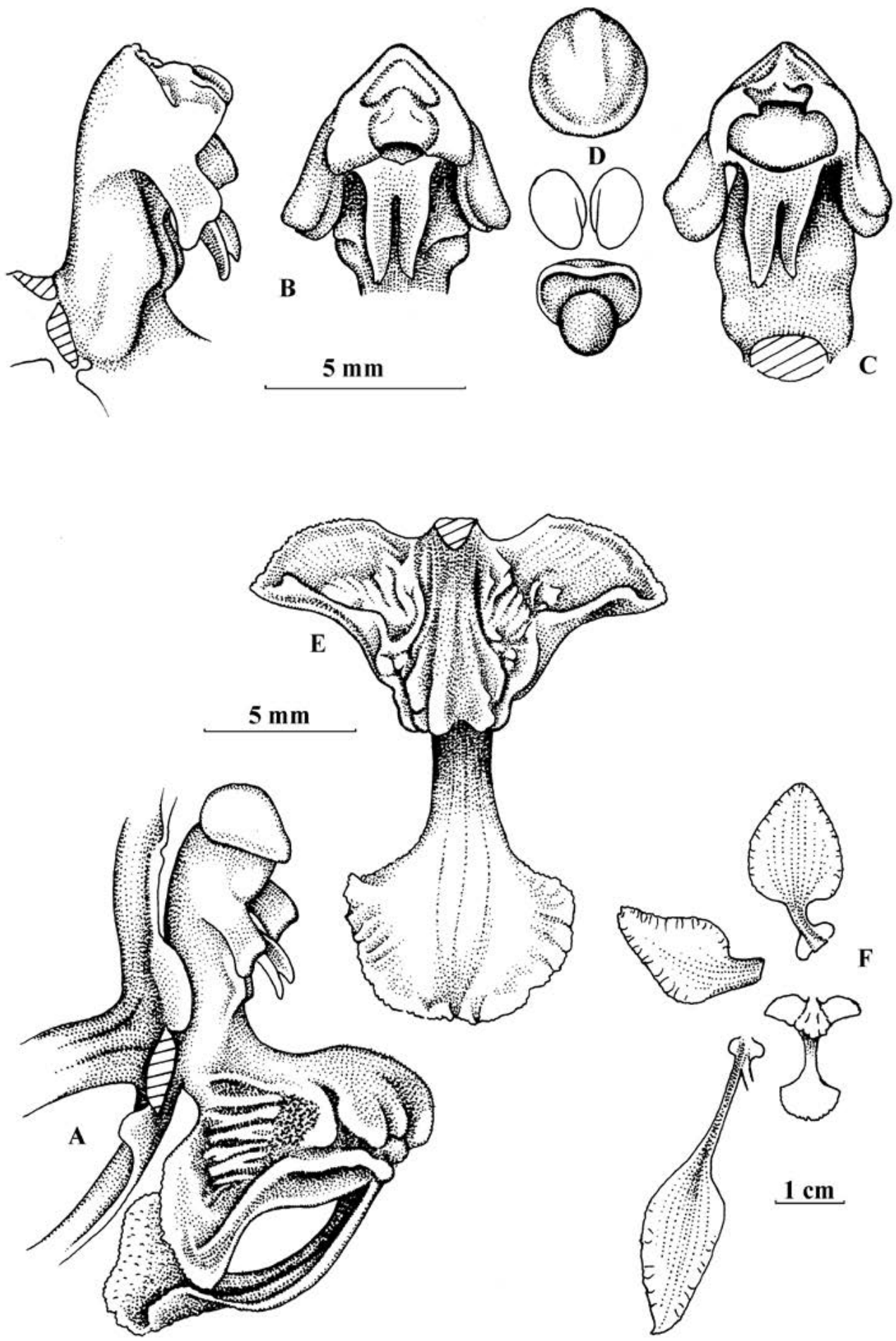

FiguRE 4. Cyrtochilum cryptocopis. A. Column and lip, lateral view. B. Column, lateral and frontal views. C. Column, ventral view. D. Anther cap and pollinarium. E. Lip, spread. F. Flower dissected. Drawn from Dalström 2800 (SEL) by Stig Dalström. 

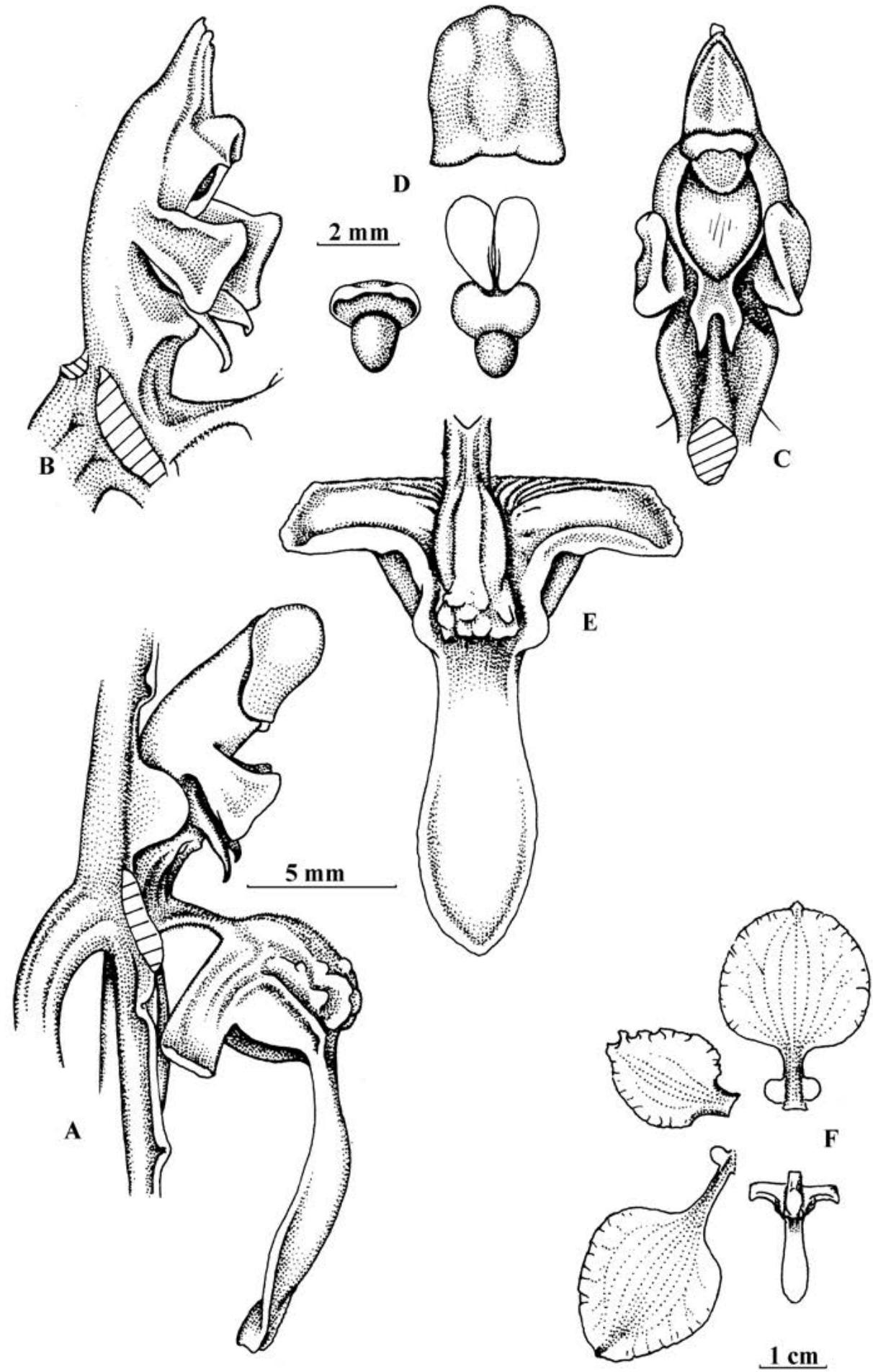

Figure 5. Cyrtochilum trifurcatum. A. Column and lip lateral view. B. Column lateral view. C. Column ventral view. D. Anther cap and pollinarium. E. Lip, spread. F. Flower dissected. Drawn from Dodson 14034 (SEL) by Stig Dalström. 
more information about the species distribution can be gathered.

ACKNOWLEDGMENTS. The authors wish to thank the NSF funded project; Flora of Las Orquideas National Park (DEB 1020623 to Pedraza), for funding the fieldwork and making specimens available, and also the New York Botanical Garden, Universidad Nacional de Colombia and Unidad de Parques Nacionales Naturales de Colombia. In addition we especially thank Hector Velásquez and the park rangers for assisting in the logistics and successfully executing the field trip. We are very thankful to Sarah Friedrich, Media Specialist in the botany department at UW-Madison for the preparation of the type illustration. The first author also thanks the botanists Julio Betancur, Paola Pedraza, Maríaa Fernanda González, and the photographer Fredy Gómez for their company and support, making the field trip an unforgettable and enriching experience.

\section{LiTERATURE CITED}

Dalström, S. 2010. Cyrtochilum Kunth, in Flora of Ecuador 225(3): Orchidaceae; genera Cyrtochiloides-Epibator, by Calaway H. Dodson and Carl A. Luer. Department of Plant and Environmental Sciences, University of Gothenburg, Sweden. 